\title{
Forest Policy Developments Développement de politiques forestières
}

\section{United Nations Conference on Environment and Development}

Resolution 89.6, passed at the 1989 Annual General Meeting of the CIF/IFC called for the United Nations to establish a follow-up to the Brundtland Commission to develop world protocols for dealing with environmental problems. The General Assembly of the United Nations at the close of its 44th Session, adopted a resolution in which it decided to convene a United Nations Conference on Environment Day, 5 June 1992. The two-week conference, which the assembly specified should be at the highest possible level of government participation, will be held in Brazil.

The Assembly's resolution sets out a broad range of objectives to be accomplished by the Conference, noting that environmental issues will need to be addressed within the development context.
A conference Preparatory Committee of the General Assembly, open to all State Members, has been created to prepare the foundations for the conference. The resolution calls for it to hold five preparatory sessions in advance of the conference. The first of these will be held in New York. The Second session will be held in Nairobi, the third and fourth in Geneva and the final session will again be held in New York.

Maurice Strong has been named as Conference Secretary-General by UN Secretary-General Javièr Pérez de Cuéllar. The conference will be run from an "ad-hoc" secretariat in Geneva with a unit in New York to liaise with UN bodies and North American groups, and one in Nairobi to liaise primarily with the UN Environment Programme.

\section{National Forestry Sector Strategy for Canada Implementation Progress Report No. 2}

Last summer the Canadian Council of Forest Ministers commissioned the preparation of a second implementation progress report on the 1987 National Forest Sector Strategy. The report follows a first report (undated) that was issued in 1988 or early 1989 . The initial progress report was prepared by the Government of Alberta, which at the time the work was carried out was responsible for providing the Council's Secretariat.

The second report was prepared by the Canadian Forestry Association. It is presented in four parts. Part one deals with the written responses to the detailed questionnaire, Part two covers the responses to the opinion poll, Part three deals with public opinion and the strategy, while Part four presents the summary and recommendations. Parts 1,2 and 4 were written by Dr. R.J. Bourchier, Forest Policy Consultant. Part 3 was written by Dr. Keith Newman, Environics Research Group Limited, and is based on the results of the public opinion poll conducted for Forestry Canada in early 1989. The report is being published by the Ontario Ministry of Natural Resources and should be available shortly.

The report is based on responses to 222 questionnaires sent to a broad array of organizations - 59 were detailed in scope and 163 were of an "opinion poll" nature. In all there were 27 usable responses to the detailed questionnaire and 67 responses to the survey. The report notes that there was a short turn around time of only three weeks, which seems to reflect a lack of advance planning.

The detailed questionnaire asked for responses to 23 questions of which six were concerned with The Forest and its Management, three with Sustainable Development, one with Environment (airborne pollutants), five with Research and Development, three with Trade and Investment and three with Employment and one with Public Awareness. The final question asked respondents to identify the single most important modification they would like to see in the strategy. The poll requested respondents to agree or disagree with 30 statements on the same topics.
The executive summary reports the following highlights:

(1) Forest Fire Management - good progress made in fire control.

(2) Federal/Provincial Forest Development Agreements recognition that agreements should be continued at meaningful levels.

(3) Research Funding - consensus that research funding has eroded, and that the trend needs to be reversed.

(4) Public Perception - the public does not accept two recommendations, use of pesticides and limits to the noncommercial use of forest lands.

(5) Forestry Awareness - more collaborative information and education programs are required.

(6) Agenda for Action - there is a sense that the strategy is drifting.

The report by Keith Newman reviews each of the Forest Sector Strategy recommendations in light of the public's current views towards forest-related issues. The author concludes that Canadians will support the strategy and most of its recommendations. However, the public will not support the two recommendations noted above. The public feels strongly that chemicals pose an unacceptable hazard and also that non-commercial uses are more important than commercial ones. Finally Canadians are looking for leadership and results, not further reports and recommendations.

The main concern with the Strategy is that it seems to be drifting and there is a need for an agenda for action with quantifiable objectives with definite time frames. This poses a challenge, but must be given attention by the CCFM. Canadians will accept the Strategy as a starting point, but will want to see it translated into visible progress towards enhancing Canada's forests. It will be interesting to see how Ministers respond to the challenge and in particular to see how increased attention will be placed on public education, integrated resource management, research and development and non-timber values. The importance of the federal government's continued commitment to federal/provincial forestry agreements was cited most frequently as the recommendation requiring implementation.

J.H. Cayford, Executive Director 


\section{Paper Recycling: The Pros and Cons ${ }^{1}$}

In the past in Canada, "waste paper", such as old newspapers, cardboard and used office paper, usually landed up in the local garbage dump. Waste paper, however, takes up a lot of space; and, as we all know, we're running out of garbage dumps. So, in addition to blighting the landscape, this practice is also becoming increasingly expensive. Recycling, then, which reduces the volume of solid waste for disposal, seems to be the only sensible solution.

Another driving force has been the recent legislation on recycling in the United States. Several states have already passed laws that require newsprint to contain recycled fibre, and many other states are considering similar legislation.

Today nearly 23 percent of the paper and paperboard consumed in Canada is collected for recycling. The aim is to increase this figure to 50 percent by 1995, which is the percentage now being obtained by South Korea, Hong Kong and Japan. These places have the highest recycle rate.

\section{Recycling Cardboard}

Cardboard is by far the most widely used grade of recovered fibre. Little special equipment is required to recycle this material and it is very economical to do so. It is estimated that 70 percent of the Canadian production of this material could be recycled if there were more collection systems set up in places such as shopping centres. At present, 50 percent is recycled.

\section{Recycling Old Newspapers}

The main issue these days, however, centres on recycling old newspapers. The success of the Ontario blue box program (a home pick-up service for newspapers, tin and glass) has spurred others outside Ontario into planning and establishing similar systems. Right now in Ontario over 100000 tonnes of newsprint are collected annually. This figure is likely to increase to over 500000 tonnes by 1993 .

Unfortunately, we now have a surplus of this material, which is expected to last a couple of years. We have a surplus because newspapers require special treatment before they can be re-used. And at the moment, most newsprint manufacturers don't have the equipment or the technology to provide this treatment. (Removing the ink from paper is one of the largest technical problems to solve.) It will take several years to design and install the necessary equipment and will cost between $\$ 50$ million and $\$ 150$ million per mill depending on the capacity.
Several large Canadian newsprint manufacturers have already announced equipment installations and more newsprint mills will follow suit. It is predicted that by 1993 , facilities will be available to handle all the newspapers collected in Canada and even large amounts from the United States.

\section{Recycling Office Paper}

Recyclable office paper is becoming another major source of supply for recycling. It is estimated that 300000 to 500000 tonnes of waste paper could be collected annually from all government and business offices in Canada. To reach this, both collection and sorting systems will have to be developed or upgraded.

\section{What Does all This Mean?}

Using recycled fibre reduces the demand on our forest, reduces energy consumption and creates some employment in the collection and sorting of wastepaper.

On the down side, some market loss could occur as machinery capable of recycling large amounts of old newspapers is installed near American cities, close to the supply. Some mill workers and loggers may lose their jobs, as less wood will be required. However, this wood could be used to produce more products to satisfy the growing demand for paper products.

\section{We'll Still Have Waste Material}

Recycling won't eliminate all waste, but it will cut it down considerably. Recycling plants will still have anywhere from 10 to 30 percent of their input material to burn or put in dumps. While newspaper recycling will reduce one source of waste, it may create another: sawmill waste. Currently large quantities of this material are used to manufacture newsprint, so other uses may have to be found for this material.

\section{More Canadian Suppliers in Future}

At present, very little paper containing recycled fibre is available in Canada. There are, however, small quantities of office paper being offered by some Canadian producers. Larger quantities are available from producers in the U.S. and other countries. However, in the near future more Canadian paper mills will start using recycled fibre, and more paper products containing this material will soon be available in Canada.

\section{The Adequate Forest Cover Club}

In 1966 the AFCC (Adequate Forest Cover Club) was born on a rainy night in the Fall of the year at a meeting of one of the branches of the Resource Rangers of Ontario where it was made public. I had been considering the establishment of a vehicle to carry an outline of action for the preservation of our environment, and felt the message to the public must be powerful in its impact but have simplicity for easy understanding and acceptance. For some years now I have used the following announcement:

\footnotetext{
${ }^{1}$ This item comes from the Forestry Canada Newsletter "Through
} the Branch" 3 (1) March 1990.

\begin{abstract}
"You are now hearing from the founder and only member of the AFCC. No, this is not a new Political Party, it is the Adequate Forest Cover Club. The objective of this Club answers the demands of the Big Four. The Big Four is not a Football League, it is a combination of four items, the preservation of which will ensure the coming generations of Canadians the finest living area in the world. By the Big Four I mean Clean Air, Clear Water, a Habitat for Wild Life, and Fibre for the Future.
\end{abstract}

These objectives can be reached by adequate forest cover, and please consider "Adequate" as minimum." 
It is my hope that in the years to come people in other countries will regard us with envy and say "Look at those crazy Canadians, still with a forested country and the finest environment in the world."

Please join me!

"Plant a tree"

\section{Founder. Max Maclaggan}

The AFCC was one of Max MacLaggan's mythical organizations that were part of his technique to arouse interest in enviromental protection.

Max, a legend in forestry circles, developed a variety of techniques designed to get his ideas across to an audience. The AFCC, or the Adequate Forest Cover Club, is in Max's words "the basis for saving Canada's natural environment. Its objectives are to ensure that Canada has sufficient forest cover to meet the demands of the Big Four - clean air, clean water, preservation of a habitat for wildlife, and an adequate supply of wood fibre for the future"'.

"It is essential for Canada to retain as much of the country as possible in a forested state". He went on to state that "if a sound basis for the future lies in the forest, then the people to take responsibility for managing them are the professional foresters". Which led him to the second mythical organization, The IRL.

An IRL would be an Industrial Recreational Licence, giving foresters control over the forested area. With the help of a biologist and a specialist in wildlife and recreation, the forester would administer his IRL to ensure that the demands of the Big Four were met.

Max, who described himself as "a bit of a humorous philosopher" caught the attention of a number of like-minded foresters. It was felt certificates should be issued to all whom Max thought worthy of receiving membership in these mythical organizations. Accordingly, membership certificates were prepared, approved by Max and signed by him for awarding to worthy recipients. Unfortunately only a hundred certificates were printed and Max, who has gone to the heavenly reward assured to all good foresters, is no longer here to sign any more. However, in March 1989, the Woodlands Section of the CPPA briefly discussed reviving the concept, perhaps in cooperation with the CIF. This is an idea the CIF might well consider.

\section{Journal Bargains for Institute Members!}

The Table of Contents of the Canadian Journal of Forest Research is carried every month in The Forestry Chronicle. Members are reminded that this prestigious forest research publication is available to them at a very special price of $\$ 36.00$ per year. The normal rate for Canadian individual subscribers for this Journal direct from NRC is $\$ 74.00$ per year in Canada and $\$ 94.00$ per year in all countries. Here then is another advantage of membership - a saving of $106 \%$ of $161 \%$ on the price of a subscription to Canadian Journal of Forest Research. Indeed, all NRC Journals are available to CIF Members at greatly reduced prices. Not for all members to be sure but a real saving for some.

Send your order and cheque to the National Office.
TOWARDS 2000

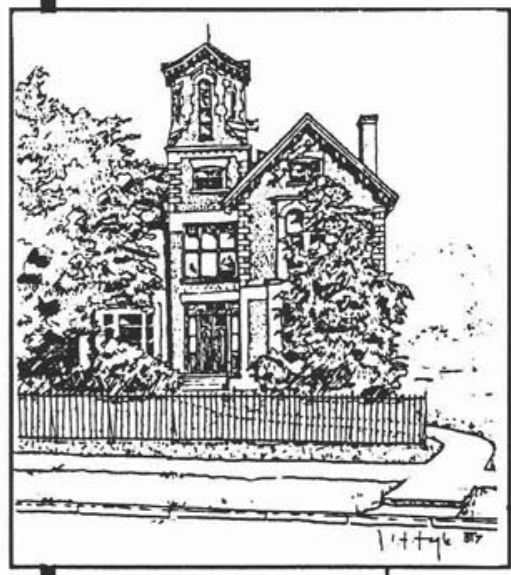

1907-1925

11 Queen's Park Cres.

Canada's very first

Faculty of Foresty was

established at the

University of Toronto in

1907 with the first

student graduating in 1909.

1926-1989

41 \& 45 St. George St.

As the Faculty grew it found new and larger quarters. In 1958 the Forestry Building was moved $75 \mathrm{~m}$ and given a new street number.

The first M.Sc.F was awarded in 1936, and the first Forestry Ph.D. was awarded in 1967.
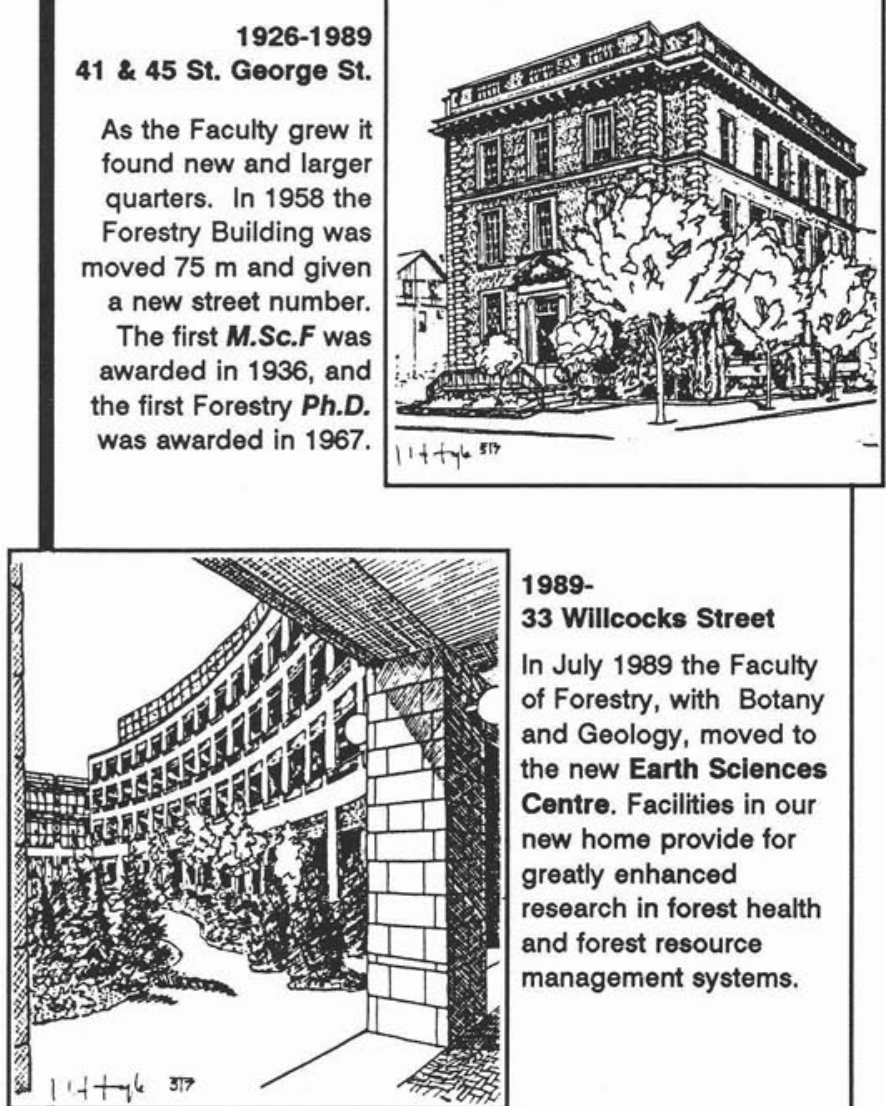

1989-

33 Willcocks Street

In July 1989 the Faculty of Forestry, with Botany and Geology, moved to the new Earth Sciences Centre. Facilities in our new home provide for greatly enhanced research in forest health and forest resource management systems.

\section{Faculty of Forestry University of Toronto}

WELCOMES IUFRO DELEGATES

to the 19th World Congress

Contact us at

Earth Sciences Centre,

33 Willcocks St.; Toronto, Ontario, Canada M5S 3B3

Tel: (416) 978-6152 FAX: (416) 978-3834 